\title{
ALTERNATIVE METHODS OF TEACHING FOREIGN LANGUAGES AT HIGHER EDUCATION ESTABLISHMENTS WITH SPECIFIC TRAINING CONDITIONS
}

\author{
АЛЬТЕРНАТИВНІ МЕТОДИ НАВЧАННЯ ІНОЗЕМНИХ МОВ \\ У ВИЩИХ ЗАКЛАДАХ ОСВІТИ ЗІ СПЕЦИФІЧНИМИ УМОВАМИ НАВЧАННЯ
}

\author{
Zapotichna R.A., \\ orcid.org/0000-0002-5588-171X \\ Lecturer of the Department of Foreign Languages \\ and Culture of Professional Speech \\ Lviv State University of Internal Affairs
}

\author{
Romanyuk O.M. \\ orcid.org/0000-0002-7053-4011 \\ Lecturer of the Department of Foreign Languages \\ and Culture of Professional Speech \\ Lviv State University of Internal Affairs
}

\begin{abstract}
Advantages and disadvantages of two foreign language teaching methods - traditional and alternative, has been portrayed in the article. The article deals with the peculiarities of the use of alternative methods of teaching foreign languages at higher education establishments with specific training conditions. Particular emphasis on modern information technology and actual trends in teaching foreign languages has been made. It has been highlighted, that such methods of teaching help students of higher education establishments with specific training conditions to upgrade their basic language skills, increase interest in educational material, allow to make educational process more effective and individualized. Some of the modern methods are not applied in traditional education, although their positive effect on students has been proved. The classification of the alternative methods of teaching foreign languages has been provided. These methods, among others, include: interactive games, multimedia presentations and internet communication technologies. The main advantages of such methods in overcoming of communicative obstacles, that often occur when students study a foreign language, has been studied. Criterion which should be taken into account during selection of innovative methods are analyzed. The importance of using games which improve speaking skills and enhance student's motivation in teaching foreign languages is emphasized. An attempt to determine the role of interactive games on teaching foreign languages, and to compare games with more traditional practices, which include case studies, group quizzes, lectures, collaborative teaching, homework, use of blackboard, has been made. It has been concluded that student's academic performance and learning abilities, as well as, their motivation to study need to be taken into consideration for the selection of the most suitable teaching method and combination of teaching applications.
\end{abstract}

Key words: alternative methods, communicative ability, foreign language, interactive games, motivation, speaking skills, teaching methods.

У статті розглянуто переваги та недоліки двох методів навчання іноземної мови - традиційного та альтернативного. Досліджено особливості використання альтернативних методів навчання іноземних мов у вищих навчальних закладах із специфічними умовами навчання. Особливий акцент зроблено на сучасних інформаційних технологіях та актуальних тенденціях викладання іноземних мов. Підкреслено, що такі методи навчання допомагають здобувачам вищої освіти, які навчаються у вищих навчальних закладах із специфічними умовами навчання, засвоїти та удосконалити основні мовні навички, підвищують інтерес до навчального матеріалу, дозволяють зробити навчальний процес більш ефективним та індивідуалізованим. Деякі із сучасних методів не застосовуються в традиційній освіті, хоча доведено їх позитивний вплив на засвоєння здобувачами вищої освіти навчального матеріалу. Здійснено класифікацію альтернативних методів навчання іноземних мов. Ці методи включають інтерактивні ігри, мультимедійні презентації та інтернет-комунікаційні технології. Вивчено основні переваги таких методів у подоланні комунікативних перешкод, які часто виникають, коли здобувачі вищої освіти вивчають іноземну мову у вищих навчальних закладах із специфічними умовами навчання. Проаналізовано критерії, які слід враховувати під час вибору інноваційних методів навчання. Наголошено на важливості використання ігор, які покращують мовленнєві навички та підвищують мотивацію здобувачів вищої освіти у вивченні іноземних мов. Зроблено спробу визначити роль інтерактивних ігор у навчанні іноземних мов та порівняти ігри з більш традиційними методами, до яких, зокрема, належать групові вікторини, лекції, спільне навчання, домашні завдання. Зроблено висновок, що для вибору найбільш підходящої методики навчання та комбінації навчальних програм необхідно враховувати показники успішності та вміння здобувачів вищої освіти, а також їхню мотивацію навчатись.

Ключові слова: альтернативні методи, іноземна мова, інтерактивні ігри, комунікативна здатність, методи навчання, мотивація, навички говоріння.

Introduction. The relevance of the present issue is caused by the strong need in alternative methods of learning foreign language and the need in lan- guage training and retraining for the modern professionals. The teaching of foreign languages has been done, mostly, by traditional or slightly sophis- 
ticated teacher-centered methods rather than modern student-oriented applications and techniques while the transmission of knowledge and information has been realized with the usual form of lectures or discussions requiring physical presence of both student and the teacher. The overarching research problem of the article can be formulated as follows: What are the set of effective alternative methods for learning and teaching the foreign languages?

The article is aimed at analyzing traditional and alternative methods for teaching and learning foreign languages, as well as to reveal and prove a set of effective pedagogical conditions for learning languages. The object of the study is the specificity of using alternative methods in teaching foreign language to the students getting higher education at the establishments with specific training conditions. The relevance of the present issue is caused by the strong need in alternative methods of learning foreign language and the need in language training and retraining for the modern professionals. The article is a general description of alternative methods of learning a foreign language

Short review of the latest publications. Many researches have shown that using alternative methods of teaching foreign languages at higher education establishments is one of the effective methods in teaching languages. Our views have been strongly influenced by the writings of M. Abdyhalykova [1], B. Frydrychov [2], N. Hodovanets, and V. Lehan [3], D. Kamalja, S. Khatik, and T. Hitesh [4], M. Mubaslat [5], all of whom have proposed models for integrating alternative and traditional language teaching culture. These works share a common conceptual core and set of intricately related assumptions regarding the teaching and learning of culture. Given the diversity of the topics, the range of literature that we have surveyed in this report is very broad. We have consulted academic journals, books, conference proceedings, technical reports and online materials.

Results and discussion. Traditional teaching methods including case studies, group quizzes, lectures and -more recently - collaborative teaching, homework, use of blackboard and - even more recently - computer programs and other techniques like the pause method, allow student participation in lectures while providing them with the opportunity to select their own learning process. Modern teaching methods, on the other hand, including contemporary software programs, distance-learning for the same end.

Alternative teaching methods include a method of complete physical reactions, suggestive method, drama-pedagogical teaching, silent and group method. Suggestive method of learning a foreign language is based on the selective lexical material commonly used in basic vocabulary. The main idea of drama-pedagogical method is that a foreign language teacher can borrow much for his professional practice from the art and actors. The method of complete physical reaction is based on concerted action and speech, speech training through physical (motor) activity. The main advantage of "silent" method is to improve oral communication skills, overcoming fear of linguistic accuracy and correctness of teaching ideas. "Group method" - basic principles of training were borrowed from the field of customer relations with consultant. It focuses on a combination of cognitive and emotional learning processes [3].

Modern stage is characterized by careful selection of methods of foreign languages teaching. Particular emphasis today is made on modern information technology and actual trends. There is a sort of selection of the most effective methods, techniques and tools during the preparation of specialists in various fields4-6. The most important goal, according to scientists is the formation of a secondary language personality. Students must take a new language to a fundamentally new level. To do this, it is important to separate it from the mother tongue, in order to avoid errors in perception. During selection of innovative methods following criteria taken into account:

- Creating a comfortable and supportive atmosphere for student, promotion of natural interest and desire to learn a new foreign language;

- Involvement of emotions, feelings, experiences in the educational process to stimulate verbal, written and creative abilities;

- Use of the cognitive approach in the educational process;

- Call to work with the language on their own at the level of emotional and physical capabilities [1, p. 2].

The process of English communication learning will be more student-centered but less time consuming. Therefore, it promises that the teaching quality will be improved and students' applied English communication can be effectively cultivated, meaning that students' communicative competence will be further developed. Language in education would ideally and ordinarily build on such naturally acquired language ability, enriching it through the development of literacy into an instrument for abstract thought and the acquisition of academic knowledge. Teachers use a range of local texts or English translation of literature in the classroom. The use of language as well as the use of a variety of accents in listening activities or tests is encouraged in the English language classroom. With the proliferation of tablets and smart 
phones, it is believed that textbooks will disappear in a few years. Furthermore, the access to knowledge in terms of flexibility and mobility has changed drastically. Teaching in English language classes focuses on fostering the students thinking as well as language content, outcomes and learning activities. There are significant and complex student-teacher interactions inside and outside the classroom. In a knowledge based society and to remain competitive and employable, teachers are expected to engage in a continuous professional development or the professional learning activities from the beginning to the end of their careers. As with any other profession, teachers are also expected to assume a greater responsibility for their own professional learning, continually developing their knowledge and skills.

New trends in English language teaching like interactive approach of teaching English is develop as a result of sustain research by the central board of secondary education (CBSE New Delhi). This approach also recommended by the Indian Council of School Education (ICSE New Delhi). To interact means to communicate which each other during interaction. Its means give the information, thoughts unknown to receiver. So interactive teaching styles are Brain Storming, Think pair and share, Buzz session, incident process, $\mathrm{Q}$ and A session. In Interactive approach some ideas are follow the leader, Total Physical Response (TPR), One word, Opposite Arguments, Test Tournaments, YouTube Videos Quizzes, Electronic Role Playing, Puzzle pieces. Communicative language teaching (CLT) emphasize on the process of communication rather than the mastery of language. Sometime the term functional approach is use for communicative approach or communicative method. In is article on communicative competence published in, «New origins in Linguistics» in 1971. The communicative approach emphasizes real meaningful communication rather than the activity, topic and situation which are artificial and remote from student's lives. Communicative approach includes three principles:

1) Which involve real communication;

2) Which involves various activities;

3) Which emphasize that language is meaningful to the learners $[4$, p. 6$]$.

We made an attempt to determine the role of educational games on learning a foreign language, and to compare games with more traditional practices as effective learning tools for students of higher educational establishments with special training conditions.

Language learning is a hard work. Effort is required at every moment and must be maintained over a long period of time. As we need meaningfulness in lan- guage learning, and authentic use of the language it is useful to follow and create many different techniques and procedures. That through creative procedure we can have an interactive environment which may lead to an improvement in learning a foreign language.

Games and especially educational games are one of the techniques and procedures that the teacher may use in teaching a foreign language. Games are often used as short warm-up activities or when there is some time left at the end of a lesson. A game should not be regarded as a marginal activity filling in odd moments when the teacher and group have nothing better to do. In our opinion, games ought to be at the heart of teaching foreign languages, games should be used at all the stages of the lesson, provided that they are suitable and carefully chosen. Games also lend themselves well to revision exercises helping learners recall material in a pleasant, entertaining way.

There is a widespread agreement that even if games resulted only in noise and entertained students, they are still worth paying attention to and implementing in the classroom, since they motivate learners, promote communicative competence and generate fluency and may have a significant role in improving a foreign language acquisition [5, p. 3-4].

There are a number of reasons that games deserve a place in the language classroom. First of all, they are fun, which is extremely important, because they can help activate students who may have been inactive before, due to lack of interest. Keeping students active is vital because teachers will never be able to actually teach students anything unless they can get them to participate in their own learning process.

Second, games also play a big part in helping participants build relationships, and to feel equal. Playing games in the classroom can also help create a friendly and positive atmosphere where seat arrangement can differ from game to game, and thus cause diversity from the norm which can be extremely helpful in keeping an exciting learning environment.

Third, the reason most people want to learn a language is to be able to use it in real situations, for example when travelling. Games can be a very good way to practice this skill because they can easily be used to reenact various situations from real life and provide students with practice in their fluency. Also, by using games in the classroom the teacher is giving his students a bigger role, and he himself is stepping out of the frontline which is a positive thing because it allows students to take on more responsibility. Also that allows students to do more on their own, and that can very well result in an increase in their confidence level. 
Fourth, language students need to be emotionally involved, meaning they need to feel something while they are exposed to the language. Strong emotions, such as happiness, excitement, amusement and suspense allow students to feel positively about their learning situation and are therefore likely to have a positive effect on language learning.

Fifth, games are good for shy students and students with low confidence, and that applies specifically when playing takes place in smaller groups because then they get a chance to speak in front of fewer audience instead of having to express themselves in front of the whole class. Also it is sometimes easier to open up and forget the shyness when playing a game because the atmosphere is not as serious and more emphasis is put on fluency rather than grammatical correctness [6, p. 8].

The language games can be divided according to different principles. These games are as follows:

- Sorting, ordering, or arranging games. For example, students have a set of cards with different products on them, and they sort the cards into products found at a grocery store and products found at a department store;

- Information gap games. In such games, one or more people have information that other people need to complete a task. For instance, one person might have a drawing and their partner needs to create a similar drawing by listening to the information given by the person with the drawing;

- Guessing games. These are a variation on information gap games. One of the best known examples of a guessing game is 20 questions, in which one person thinks of a famous person, place, or thing. The other participants can ask 20 yes/no questions to find clues in order to guess who or what the person is thinking of;

- Search games. These games are yet another variant on two-way information gap games, with everyone giving and seeking information. Find Someone Who is a well-known example. Students are given a grid. The task is to fill in all the cells in the grid with the name of a classmate who fits that cell, e.g. someone who is a vegetarian. Students circulate, asking and answering questions to complete their own grid and help classmates complete theirs;

- Matching games. As the name implies, participants need to find a match for a word, picture, or card. For example, students place 30 word cards, composed of 15 pairs, face down in random order. Each person turns over two cards at a time, with the goal of turning over a matching pair, by using their memory; - Labelling games. These are a form of matching, in that participants match labels and pictures;

- Exchanging games. In these games, students barter cards, other objects, or ideas;

- Board games. Scrabble is one of the most popular board games that specifically highlights language;

- Role play games/dramas. Role play can involve students playing roles that they do not play in real life, such as dentist, while simulations can involve students performing roles that they already play in real life or might be likely to play, such as customer at a restaurant. Dramas are normally scripted performances, whereas in role plays and simulations, students come up with their own words, although preparation is often useful [2, p. 1157-1158].

Conclusions. It should be noted however that, students' background knowledge, academic performance and learning abilities need to be taken into consideration for the selection of the most suitable teaching method and combination of teaching applications. It should be also mentioned that, learning a foreign language is largely determined by the motivation of the students of higher education establishments with specific training conditions. In order to improve the process of teaching and learning as well as the understanding of the subject, specific strategies and educational techniques should be developed that take into account also, what motivates students and how these motivators can be strengthened.

\section{REFERENCES:}

1. Abdyhalykova M. Innovative Methods of Foreign Languages Teaching. Indian Journal of Science and Technology. 2016. Vol. 9 (22). P. 1-7.

2. Frydrychov B. Games in the Teaching of English. Procedia - Social and Behavioral Sciences. 2015. Vol. 191. P. $1157-1160$

3. Hodovanets N., and Lehan V. To the Summary of Alternative Methods of Teaching Foreign Languages. International Scientific and Practical Conference "WORLD SCIENCE". 2016. Vol. 3(7). P. 29-31.

4. Kamalja D., Khatik S., and Hitesh T. Modern Approaches and Methods in Teaching English Language. International Journal of Research \& Innovation. International Journal of Research \& Innovation. 2014. Vol. 2(3). P. 8-12.

5. Mubaslat M. The Effect of Using Educational Games on the Students' Achievement in English Language for the Primary Stage. International review of social sciences and humanities. 2012. Vol. 4 (2). P. 1-14.

6. Sigurðardóttir S. The use of games in the language classroom. International Journal of Academic Research in Progressive Education and Development. 2010. Vol. 7 (2). P. 6-25. 